\title{
APRENDIZAGEM COOPERATIVA E COLABORATIVA NO ENSINO DE EQUILÍBRIO QUÍMICO A CALOUROS
}

\author{
Carolina Sotério $^{a}$, Daniel Lino Teodoro e Salete Linhares Queiroz $^{\mathrm{a}, *,(0)}$ \\ anstituto de Química de São Carlos, Universidade de São Paulo, 13560-970 São Carlos - SP, Brasil
}

Recebido em 04/04/2021; aceito em 19/07/2021; publicado na web em 17/08/2021

\begin{abstract}
COOPERATIVE AND COLLABORATIVE LEARNING TO TEACH CHEMICAL EQUILIBRIUM TO FRESHMAN STUDENTS. This paper describes cooperative (jigsaw) and collaborative activities (Peer-Led Team Learning) carried out in the BSc degree in Chemistry at the São Carlos Institute of Chemistry, the University of São Paulo, Brazil. The dynamics of discursive interactions established among students in the cooperative and collaborative groups was investigated based on the Model proposed by Kumpulainen and Mutanen, by analyzing the following: functions of speech, cognitive processing and social processing. In this perspective, the influence of the level of structure of the activities was studied. The results obtained point to the possibility of adapting both types of activities in higher education chemistry courses.
\end{abstract}

Keywords: cooperative learning; collaborative learning; chemistry.

\section{INTRODUÇÃO}

O primeiro ano do curso de graduação em química tem um papel essencial no percurso formativo dos ingressantes, especialmente por se tratar de um período de adaptação em que a bagagem de conhecimentos prévios contrasta com os novos conhecimentos a serem construídos. Nesse momento, obstáculos enfrentados durante o processo de aprendizagem podem se tornar preponderantes, exigindo, assim, estratégias que os minimizem. ${ }^{1}$

A capacidade de abstração e a assimilação de conceitos básicos são dificuldades recorrentes. ${ }^{1,2}$ No que diz respeito à temática do equilíbrio químico, em destaque neste manuscrito, a dificuldade no seu aprendizado relaciona-se, segundo Bertotti, ${ }^{3}$ "tanto no que diz respeito a aspectos de caráter mais conceitual quanto aos associados a um tratamento quantitativo do assunto" (p.1839).

Dessa forma, o planejamento das disciplinas, em especial as introdutórias, precisa considerar os problemas usualmente enfrentados na aprendizagem dos conteúdos nelas ministrados. ${ }^{1-3} \mathrm{Nessa}$ perspectiva, documentos curriculares, assim como pesquisadores da área de Educação em Química, apontam para a necessidade do rompimento de paradigmas antigos e da valorização do estudante, por intermédio de práticas pedagógicas inovadoras, que propiciem a compreensão de conceitos químicos fundamentais desde o início da jornada universitária. ${ }^{4,5}$

Com o intuito de contribuir com práticas pedagógicas que dialogam com este novo paradigma, trabalhos reportados na literatura têm se pautado nos princípios da aprendizagem cooperativa e colaborativa no âmbito do ensino de química, tanto em disciplinas práticas quanto teóricas. Entre os benefícios apontados pelos autores como delas decorrentes estão o desenvolvimento de habilidades comunicativas, de resolução de conflitos e criticidade, existindo, inclusive, alternativas viáveis de condução de atividades online, em situações como a atual pandemia de COVID-19.6,7

Diante de tal cenário, o formato jigsaw tem se destacado no âmbito cooperativo, sendo relatado inclusive em publicações desta revista. ${ }^{5,8}$ Com base no trabalho em equipe - na qual cada membro possui funções específicas em prol de um objetivo comum - esta metodologia organiza os alunos em grupos, denominados de base e de especialistas, e promove um exercício multifacetado e simultâneo,

*e-mail: salete@iqsc.usp.br possibilitando ao docente construir relações positivas em sala de aula. ${ }^{9}$ No entanto, nada se encontra no escopo deste periódico sobre o formato colaborativo peer-led team learning (PLTL) que, por sua vez, tem a liderança estudantil como um elemento unificador chave. Essa abordagem preserva a aula expositiva e traz em seu bojo uma nova estrutura, na qual os alunos interagem para resolver problemas sob a orientação de um líder-par. ${ }^{10}$

Isso exposto, o presente manuscrito tem como objetivo relatar a realização de atividades didáticas desenvolvidas nos moldes da aprendizagem cooperativa (grupos jigsaw) e colaborativa (grupos PLTL), assim como analisar a dinâmica da interação dos alunos participantes em cada uma delas, buscando responder a seguinte questão de pesquisa: qual é a influência da estrutura dos grupos na forma como as interações discursivas entre os participantes são estabelecidas? As interações foram analisadas segundo o Modelo Analítico de Kumpulainen e Mutanen (MAKM) ${ }^{11}$ descrito sucintamente em tópico a seguir e os dados foram coletados junto aos ingressantes de um Curso de Bacharelado em Química, na disciplina Introdução à Química. $\mathrm{O}$ alcance de respostas à questão de pesquisa pode oferecer subsídios para o delineamento de ações educativas nos cursos de graduação em química, com ênfase nas disciplinas introdutórias.

\section{MODELO ANALÍTICO DE KUMPULAINEN E MUTANEN ${ }^{11}$}

O MAKM tem como objetivo principal investigar a natureza das atividades sociais dos alunos, em especial as interações verbais realizadas em diferentes situações de aprendizagem. No entanto, o Modelo não se restringe apenas a tais interações, também permite que se entenda a construção do conhecimento, valorizando o caráter da atividade, momento a momento, tendo como foco de análise o aluno e o grupo. Para tanto, descreve a dinâmica das interações estabelecidas entre os membros do grupo, envolvendo três dimensões: funções da fala, processamento cognitivo e processamento social.

\section{Primeira dimensão: funções de fala}

No que diz respeito à primeira dimensão, são investigadas as estratégias comunicativas adotadas pelos alunos enquanto interagem com os colegas, buscando determinar quais são os significados funcionais das suas falas. Funções de fala podem refletir as 
expectativas dos alunos frente ao contexto sociocultural da atividade didática proposta pelo professor e permitem interpretar a evolução da situação criada pela atividade. A identificação das funções de fala está relacionada com a base do que o orador fala, ou seja, aquilo que sua fala pode implicar ou sugerir. Algumas dessas funções descrevem a natureza da interação com ênfase nas demandas exigidas pela tarefa, enquanto outras enfatizam a perspectiva social ou cognitiva das interações em grupo.

Com o intuito de facilitar a análise das interações discursivas na perspectiva das funções de fala, elas foram distribuídas em três blocos.

O primeiro bloco é composto pelas funções de fala dos seguintes tipos: interrogação (Int), resposta (Res), complemento de resposta (C-Res), informação (Inf) e leitura em voz alta (LVA). Essas funções foram agrupadas por serem capazes de refletir as interações entre os alunos na busca direta e objetiva pela resolução da atividade proposta pelos professores. O segundo bloco é composto pelas funções de fala dos seguintes tipos: organização de ação (Org-A), experiencial (Exp), julgamento (Jul), avaliação (Ava) e afetiva (Afe). Essas funções foram agrupadas por serem capazes de refletir as interações ocorridas entre os interlocutores na perspectiva de interação social. Elas são, entre as demais, as que melhor refletem a interação social ocorrida entre os alunos. É com elas que eles julgam, avaliam, organizam e até elogiam seus pares. Por fim, o terceiro bloco é composto pelas funções de fala dos seguintes tipos: resposta crítica (Res-C), complemento de resposta crítica (C-Res-C), citação crítica (Cit-C) e organização de ideia (Org-I). Essas funções foram agrupadas por serem capazes de refletir as interações entre os alunos baseadas em exercício críticoreflexivo com demanda cognitiva complexa.

O Quadro 1 ilustra as funções de falas, adaptadas para a nossa análise, a partir do MAKM.

\section{Segunda dimensão: processamento cognitivo}

No que diz respeito à segunda dimensão, são investigadas as estratégias adotadas pelos alunos, do ponto de vista cognitivo, na resolução da tarefa solicitada pelo professor, as quais podem ser categorizadas conforme ilustra o Quadro 2.

\section{Terceira dimensão: processamento social}

Essa dimensão diz respeito à caracterização das relações sociais construídas pelos grupos em um intervalo de tempo determinado. Com a finalidade de adequar as categorias ao presente contexto de estudo, a classificação dos momentos registrados se deu em quatro modos distintos e não-competitivos de interação, elaborados a partir do MAKM: o modo colaborativo é compreendido como uma situação na qual há uma participação de igual contribuição dos estudantes na execução de suas tarefas; e o tutorial como um

Quadro 1. Categorização e descrição da primeira dimensão (funções de fala) do MAKM

\begin{tabular}{|c|c|c|c|}
\hline & Categoria & Sigla & Descrição \\
\hline \multirow{5}{*}{ Bloco 1} & Interrogação & Int & $\begin{array}{l}\text { Quando o aluno elabora uma questão ou faz referência a uma questão feita pelo profes- } \\
\text { sor ou por outro membro do grupo. }\end{array}$ \\
\hline & Resposta Direta & Res & $\begin{array}{l}\text { Quando a fala do aluno busca responder uma pergunta dita anteriormente de forma } \\
\text { simples e objetiva. }\end{array}$ \\
\hline & Resposta Crítica & Res-C & Quando a resposta do aluno parte de uma análise mais aprofundada e elaborada. \\
\hline & Informação & Inf & $\begin{array}{l}\text { Quando ocorre o fornecimento de informação, desde que essa informação não tenha } \\
\text { como objetivo responder uma pergunta ou organizar ideia ou ação. }\end{array}$ \\
\hline & Leitura em Voz Alta & LVA & $\begin{array}{l}\text { É caracterizada pela leitura de um material em voz alta. Seja esse material produzido } \\
\text { pelo leitor, por outro membro do grupo ou por terceiros. }\end{array}$ \\
\hline \multirow{5}{*}{ Bloco 2} & Organização de Ação & Org-A & Quando a fala do aluno tem o objetivo de organizar o grupo ou a atividade. \\
\hline & Experiencial & Exp & Quando ocorre uma fala relatando experiências pessoais. \\
\hline & Julgamento & Jul & $\begin{array}{l}\text { Quando as falas buscam concordar ou discordar com ações ou ideias dos demais } \\
\text { membros do grupo. }\end{array}$ \\
\hline & Avaliação & Ava & $\begin{array}{l}\text { Quando o aluno faz uma avaliação de uma ação ou ideia que tenha partido do grupo } \\
\text { ou de um membro do grupo. }\end{array}$ \\
\hline & Afetiva & Afe & É caracterizada quando ocorre expressão de sentimentos. \\
\hline \multirow{5}{*}{ Bloco 3} & Citação Crítica & Cit-C & Quando o aluno tenta justificar ou refutar ideias ou ações. \\
\hline & Organização de Ideia & Org-I & $\begin{array}{l}\text { É caracterizada quando a fala do aluno tem o objetivo de organizar as ideias expostas } \\
\text { buscando a melhor resposta. }\end{array}$ \\
\hline & Complemento de Resposta & C-Res & É caracterizada por falas que complementam sentidos de respostas dadas anteriormente. \\
\hline & Complemento de Resposta Crítica & C-Res-C & $\begin{array}{l}\text { É caracterizada por falas que complementam sentidos de respostas que partam de uma } \\
\text { análise mais aprofundada, que tenham sido dadas anteriormente. }\end{array}$ \\
\hline & Inclassificável & Inc & É caracterizada por funções que não podem ser classificadas nas demais funções. \\
\hline
\end{tabular}

Adaptado de Kumpulainen e Mutanen. ${ }^{11}$

Quadro 2. Categorização e descrição da segunda dimensão (processamento cognitivo) do MAKM

\begin{tabular}{|c|l|l|}
\hline Categoria & Sigla & Descrição \\
\hline Procedural & PCR & Atividade rotineira, que exige apenas a manipulação, organização e execução de tarefas sem análise reflexiva. \\
\hline Off-task & PCO & Atividade não relacionada à tarefa solicitada pelo professor. \\
\hline Interpretativo ou Exploratório & PCE & $\begin{array}{l}\text { Atividade crítica e exploratória, que inclui planejamento, levantamento de hipóteses, avaliação e } \\
\text { experimentação. }\end{array}$ \\
\hline
\end{tabular}


evento no qual um suporte é oferecido pelos próprios estudantes ou pelo líder-par aos membros do grupo, tendo em vista a execução de uma determinada atividade. O processamento social do tipo individualista é caracterizado pelo trabalho individual do estudante, sem compartilhamento das dúvidas e conclusões com os demais membros do grupo, ou pelo domínio de um dos membros na realização da tarefa. Por fim, o processamento social do tipo competitivo é definido como modo de conflito, caracterizado pela ocorrência de conflitos sociais ou acadêmicos não solucionados.

\section{PERCURSO METODOLÓGICO}

\section{Contexto de aplicação da proposta}

A atividade cooperativa (jigsaw) e a colaborativa (PLTL) sobre equilíbrio químico foram levadas a cabo em horário extraclasse na disciplina Introdução à Química, oferecida aos alunos ingressantes do Curso de Bacharelado em Química do Instituto de Química de São Carlos da Universidade de São Paulo (IQSC/USP).

A disciplina, de caráter obrigatório, é ministrada em quatro horas semanais e visa à discussão e o fornecimento ao aluno de uma fundamentação teórica geral da química, demonstrando a lógica do aprendizado e enfocando tanto aspectos fenomenológicos, quanto aplicações do dia a dia relacionadas aos conteúdos abordados. No primeiro dia de aula a disciplina contava com sessenta alunos matriculados, não ocorrendo nenhuma adição ou desistência, e esse número se manteve até o final do semestre, com os alunos divididos em duas turmas de forma igualitária, cada uma com seu respectivo docente. Participaram, inicialmente, das atividades didáticas, realizadas em período extraclasse, 34 alunos, sendo dezessete alunos provenientes de cada turma

Os alunos foram divididos em sete grupos, cinco grupos heterogêneos de cinco membros, isso é, formados por integrantes com diferentes perfis, níveis de motivação e conhecimento prévio para realizar a atividade proposta (formato jigsaw) e dois grupos não heterogêneos de cinco e quatro membros (formato PLTL).

Dos 34 alunos participantes, 23 cumpriram todas as etapas e foram tomados como sujeitos na investigação das interações discursivas estabelecidas nos grupos cooperativos jigsaw e nos grupos colaborativos PLTL. As atividades, formato jigsaw e PLTL, foram executadas em três etapas. Para ambos os formatos, a primeira etapa diz respeito à formação dos grupos e a segunda à vinculação da atividade extraclasse com as aulas regulares da disciplina, enquanto a última corresponde à descrição das atividades em grupo, todas realizadas no intervalo de, aproximadamente, uma hora, em três ocasiões. Cada etapa é descrita a seguir, para ambos os formatos.

\section{Etapa 1: Formação de grupos}

Formato Jigsaw: grupos heterogêneos foram formados com base na aplicação de um questionário de caracterização preenchido pelos alunos com informações sobre a sua formação estudantil e em respostas elaboradas por eles na resolução de questões sobre conteúdos de química adaptadas do trabalho de França, Marcondes e Carmo. ${ }^{12}$

Formato PLTL: grupos não heterogêneos foram formados, uma vez que a heterogeneidade não é uma prerrogativa nesta metodologia. Porém, outras exigências foram consideradas para tanto, conforme mencionado anteriormente: a integração da atividade com as atividades regulares da disciplina e com o conteúdo e a presença do chamado líder-par. ${ }^{10} \mathrm{~A}$ integração ocorreu por meio da participação dos docentes responsáveis pela disciplina nas atividades do grupo, no que diz respeito ao planejamento e desenvolvimento das ações didáticas e dos materiais utilizados. O papel de líder-par foi assumido por um aluno de pós-graduação, voluntário da pesquisa e segundo autor do presente manuscrito, que já cursou a disciplina e tem amplo conhecimento do conteúdo ministrado. O seu papel consiste em facilitar o aprendizado dos membros do grupo, a partir do estímulo ao seu engajamento com os demais membros e com o material em estudo, e não em responder perguntas colocadas por eles.

\section{Etapa 2: Aulas regulares da disciplina}

Formato Jigsaw e PLTL: no primeiro dia de aula, os docentes, em cada uma das suas respectivas turmas, apresentaram a disciplina, informando o conteúdo a ser ministrado e principais objetivos. Em seguida, os alunos entraram em contato com a proposta aqui descrita, de caráter não obrigatório, e aqueles que concordaram em dela participar assinaram Termo de Consentimento Livre e Esclarecido (TCLE). No decorrer do semestre, os conteúdos ministrados nas aulas expositivas eram retomados e discutidos nos grupos cooperativos e colaborativos.

\section{Etapa 3: Atividades no formato jigsaw e PLTL (extraclasse)}

As atividades em grupo foram realizadas, conforme mencionado, em horário extraclasse, em três ocasiões, e foram denominadas de Atividade I, Atividade II e Atividade III. O Quadro 3 sumariza cada uma delas, nos respectivos formatos (jigsaw e PLTL), que são descritos sucintamente, a seguir.

\section{Atividade I}

Jigsaw: foi entregue um mesmo questionário (disponível como Material Suplementar), com cinco questões, relativas ao tema equilíbrio químico, abordado nas aulas regulares, aos alunos membros dos cinco grupos de base, constituídos por cinco membros. O objetivo dessa primeira etapa do jigsaw é a discussão, de caráter geral, de um determinado assunto (no caso, o equilíbrio químico e seus desdobramentos), por todos os membros, tendo em vista o alcance de uma resposta coletiva sobre os questionamentos postos.

Concluídas as respostas às referidas questões, cada aluno ficou responsável por aprofundar seus conhecimentos, antes do início da próxima sessão, em um dos quatro subtópicos, que seriam alvo de discussão nos grupos de especialistas, durante a realização da Atividade II: efeito do íon comum; ácido e base; titulação e equilíbrio

Quadro 3. Atividades componentes da Etapa 3 nos formatos jigsaw e PLTL

\begin{tabular}{|c|c|c|c|}
\hline Formato & Atividade I & Atividade II & Atividade III \\
\hline Jigsaw & $\begin{array}{c}\text { Grupos de Base: } \\
\text { resolução de questionário geral sobre } \\
\text { equilíbrio químico e atribuição de tarefa } \\
\text { para a próxima aula }\end{array}$ & $\begin{array}{c}\text { Grupos de Especialistas: } \\
\text { resolução de questionários específicos so- } \\
\text { bre: efeito do íon comum, ácidos e bases, } \\
\text { titulação e equilíbrio químico }\end{array}$ & $\begin{array}{c}\text { Retorno aos Grupos de Base: } \\
\text { resolução de questionário geral, de maior } \\
\text { dificuldade, com todos os temas estudados } \\
\text { nos grupos de especialistas }\end{array}$ \\
\hline PLTL & $\begin{array}{c}\text { Todos os Grupos: } \\
\text { resolução de questionário geral sobre } \\
\text { equilíbrio químico e atribuição de tarefa } \\
\text { para a próxima aula }\end{array}$ & $\begin{array}{c}\text { Todos os } \\
\text { resolução de questionários específicos so- } \\
\text { bre: efeito do íon comum, ácidos e bases, } \\
\text { titulação e equilíbrio químico }\end{array}$ & $\begin{array}{c}\text { Todos os Grupos: } \\
\text { resolução de questionário geral, de maior } \\
\text { dificuldade, com todos os temas }\end{array}$ \\
\hline
\end{tabular}


químico. Cabe lembrar que, como cada grupo era composto por cinco alunos, o subtópico equilíbrio químico foi designado para dois alunos de cada grupo de base, os quais foram orientados a pesquisá-los em dois livros distintos de Química Geral. ${ }^{13,14}$

PLTL: O mesmo questionário proposto aos grupos de base do jigsaw foi aplicado aos dois grupos PLTL. No entanto, para alcançar a formulação das respostas os alunos contaram com o auxílio do líder-par, que esteve presente durante toda a sessão. Na sequência, os alunos foram incumbidos de aprofundar seus conhecimentos, antes do início da próxima sessão, sobre os seguintes subtópicos: efeito do íon comum; ácido e base; titulação; e equilíbrio químico. Os alunos foram orientados a pesquisar os tópicos nos mesmos dois livros indicados para os alunos dos grupos jigsaw. ${ }^{13,14}$

Diferentemente da abordagem no formato jigsaw, a estrutura mais flexível do PLTL permitiu aos alunos o estudo de uma forma não prescritiva, ou seja, sem uma definição prévia sobre um subtópico específico a respeito do qual era necessário se debruçar. A estrutura rígida do jigsaw demandou a indicação para cada aluno sobre o subtópico que deveria estudar, caso contrário, a próxima etapa da atividade estaria inviabilizada.

\section{Atividade II}

Jigsaw: os alunos de grupos de base diferentes, mas que foram designados a estudar o mesmo subtópico, discutiram sobre ele em um novo grupo (denominado grupo de especialistas). $\mathrm{O}$ objetivo dessa segunda etapa do jigsaw é propiciar que cada aluno discuta e solucione questões com membros de outros grupos a quem foi destinado o mesmo subtópico, especializando-se, portanto, sobre o assunto. Assim, por exemplo, os alunos especialistas em equilíbrio químico investigaram características comuns ao tema, tratando o tópico na perspectiva dos dois livros indicados. Nessa sessão, os alunos receberam um novo questionário, a partir do qual tiveram um contato mais aprofundado sobre as características do seu subtópico específico. Ou seja, um questionário foi desenvolvido de forma direcionada para cada subtópico e entregue a cada grupo nele especialista, totalizando quatro (disponíveis como Material Suplementar): efeito do íon comum (composto de cinco questões); ácido e base (composto de três questões); titulação (composto por três questões); e equilíbrio químico (composto por cinco questões). Em seguida, foi promovida uma discussão de modo que os alunos de cada grupo chegaram a uma resposta considerada satisfatória e desenvolveram um material que a representava.

PLTL: os alunos de cada grupo receberam os mesmos quatro questionários que haviam sido entregues a cada um dos grupos especialistas do formato jigsaw. Em seguida, foi solicitado aos alunos que, em conjunto, decidissem quais questões, dentre as apresentadas, julgavam mais relevantes para a compreensão do assunto equilíbrio químico. Após a escolha, os alunos, juntamente com líder-par discutiram e chegaram a uma resposta considerada satisfatória. Por fim, desenvolveram um material que representava a melhor resposta para o grupo.

\section{Atividade III}

Jigsaw: os alunos participantes dos grupos de especialistas retornaram aos seus grupos de base e compartilharam com os demais alunos o conhecimento ali adquirido. $\mathrm{O}$ objetivo dessa terceira etapa do jigsaw é propiciar que cada aluno apresente o que aprendeu sobre o seu subtópico aos colegas, de modo que os conhecimentos fundamentais sobre o tópico central sejam compreendidos por todos. Ou seja, cada membro do grupo de especialista precisa ter a aquisição de conhecimentos sobre o subtópico e também os explicar no retorno ao grupo de base. Cabe destacar que, tendo sido seguida tal estruturação, ficou estabelecida a interdependência positiva de recursos entre os estudantes, ${ }^{9}$ uma vez que cada um deles, ao retornar ao grupo de base, estava de posse de recursos/conhecimentos essenciais, adquiridos no grupo de especialista, para o cumprimento da atividade final, descrita a seguir. Somente com a combinação de tais recursos/conhecimentos, o grupo seria capaz de atingir o seu alvo e isso ocorreria, necessariamente, sem uma figura de autoridade presente no mesmo.

Nesse contexto, os alunos produziram respostas para um novo questionário (disponível como Material Suplementar) com os mesmos preceitos do inicial, porém com um grau de dificuldade maior. Esse questionário contava com cinco questões que tratavam dos quatro temas abordados anteriormente de forma a relacioná-los, dando mais profundidade ao conteúdo. Os alunos estavam, a princípio, munidos de uma visão privilegiada sobre os subtópicos apresentados. No final da realização do jigsaw todos os membros dos grupos entraram em contato com todos os subtópicos da atividade.

PLTL: os alunos de cada grupo receberam o mesmo novo questionário que os alunos dos grupos de base dojigsaw e elaboraram suas respostas. Eles também estavam, a princípio, munidos de uma visão privilegiada sobre os tópicos, decorrente da execução das atividades anteriores. Novamente, a sessão foi realizada com o auxílio do líder-par que, junto com os alunos, direcionou as atividades procurando dirimir eventuais dúvidas sobre as questões em estudo.

Uma síntese ilustrativa das atividades do jigsaw e PLTL, anteriormente descritas, constam como Material Suplementar.

\section{Coleta e análise de dados}

Os 23 participantes que cumpriram todas as etapas aqui relatadas foram tomados como sujeitos na investigação das interações discursivas estabelecidas nos grupos cooperativos e colaborativos. Os dados obtidos a partir da realização da pesquisa constituíram-se de gravações de áudio das atividades de pequenos grupos e questionários aplicados tendo em vista a formação de grupos heterogêneos no formato jigsaw.

As interações discursivas de dois grupos cooperativos, denominados de Grupo 1 e Grupo 2, e dos dois grupos colaborativos, denominados de Grupo 3 e Grupo 4, foram investigadas a partir do MAKM. Para tanto, mapas analíticos foram elaborados, conforme ilustrado no Quadro 4. No mapa analítico, temos duas unidades de análise: a primeira, chamada de unidade de mensagem, é referente a uma exposição verbal que possa representar uma mensagem, sendo que cada unidade de mensagem foi numerada e classificada na primeira dimensão (função de fala) e na segunda dimensão (processamento cognitivo); a segunda unidade é marcada por períodos de tempo determinados de 2 minutos, tendo sido classificada na terceira dimensão (processamento social). Os fragmentos proferidos por sujeitos que não fossem os alunos foram transcritos, mas não foram classificados. Assim, o Quadro 4 mostra como o mapa foi construído para cada um dos grupos, permitindo a organização e a posterior análise dos dados. O exemplo corresponde a um trecho do mapa analítico da primeira atividade do Grupo 1 (grupo de base do jigsaw). Cabe destacar que esta metodologia de análise de dados já foi utilizada em trabalho anterior de nossa autoria. ${ }^{15}$

Cada mapa analítico foi construído separadamente por dois pesquisadores (segundo e terceiro autores deste manuscrito), que analisaram e classificaram cada mapa. Após a finalização dos mapas, os pesquisadores reuniram-se para verificar possíveis incoerências na classificação das unidades de mensagens. Juntos, eles revisaram cada um dos mapas, dando uma classificação final para cada um deles. Esse procedimento fortaleceu a análise, corrigindo possíveis incoerências e dando uma uniformidade aos dados discutidos. A seguir, apresentaremos algumas considerações e premissas que subsidiaram a construção dos mapas: 
Quadro 4. Trecho do mapa analítico das interações ocorridas na primeira atividade do Grupo 1. Exemplificação das unidades de análise que constituem o mapa

\begin{tabular}{|c|c|c|c|c|}
\hline $\begin{array}{l}\text { Unidade de } \\
\text { Mensagem }\end{array}$ & $\begin{array}{l}\text { Função de } \\
\text { fala }\end{array}$ & Fragmentos da transcrição & $\begin{array}{l}\text { Processo } \\
\text { Cognitivo }\end{array}$ & Agente \\
\hline 169 & Int & $\begin{array}{l}\text { Você concorda que se não dá para perceber a mudança visualmente é porque está } \\
\text { ocorrendo lentamente? }\end{array}$ & PCE & A4 \\
\hline 170 & Cit-C & Se estivesse acontecendo rapidamente, você veria. & PCE & A4 \\
\hline 171 & Jul & Não. & PCR & A5 \\
\hline 172 & Cit-C & $\begin{array}{c}\text { Não é porque está acontecendo rápido ou devagar, é porque está acontecendo ao } \\
\text { mesmo tempo. }\end{array}$ & PCE & A5 \\
\hline 173 & C-Res-C & $\begin{array}{l}\text { Por exemplo, ao mesmo tempo em que você tem, vamos supor, rápido ou lento, o } \\
\text { produto formando o reagente, o reagente vai estar formando o produto. }\end{array}$ & PCE & A5 \\
\hline 174 & C-Res-C & A concentração vai permanecer. & PCE & A1 \\
\hline 175 & C-Res & Vai ficar elas por elas. & PCR & A5 \\
\hline 176 & Cit-C & Você vê só o produto e o reagente, você não vê o caminho. & PCE & A1 \\
\hline 177 & Org-I & $\begin{array}{c}\text { Então, se no produto e no reagente fica sempre a mesma concentração, independente da } \\
\text { velocidade, você só vai ver a concentração. }\end{array}$ & PCE & A1 \\
\hline 178 & Jul & É. & PCR & A5 \\
\hline 179 & Inc & Pode ser rápido ou lento, mas... & & A5 \\
\hline 180 & Int & Onde é que você está? & PCR & A5 \\
\hline 181 & Org-A & Volta aí. & PCR & A1 \\
\hline 182 & Org-I & $\begin{array}{l}\text { No estabelecimento do equilíbrio químico, as velocidades das reações diretas e inversas } \\
\text { se igualam, ou seja, as reações não cessam, apesar de visualmente. }\end{array}$ & PCE & A1 \\
\hline 183 & Org-I & As características do sistema permanecerão as mesmas. & PCE & A5 \\
\hline 184 & Int & Não é? & PCR & A5 \\
\hline 185 & Int & Aparentarem, alguma coisa assim? & PCR & A1 \\
\hline 186 & Res & Acho que nem é aparentarem, é a mesma característica. & PCR & A5 \\
\hline 187 & Int & Não é? & PCR & A5 \\
\hline 188 & Res & É que ele colocou aqui para ver como vamos escrever. & PCR & A1 \\
\hline 189 & Org-I & $\begin{array}{l}\text { As reações não param, apesar de a gente, olhando, parecer que elas pararam, que a } \\
\text { reação parou. }\end{array}$ & PCE & A1 \\
\hline 190 & Int & Hum? & PCR & A5 \\
\hline 191 & Int & Entendeu? & PCR & A1 \\
\hline 192 & LVA/Res & Ele colocou assim: apesar de visualmente parecer que a reação para. & PCR & A1 \\
\hline Tempo & $14 \mathrm{~min}$ & Processamento social: Colaborativo & & \\
\hline
\end{tabular}

Int = interrogação; Res = resposta direta; C-Res = complemento de resposta; C-Res-C = complemento de resposta crítica; Org-A = organização de ação; Org-I = organização de Ideia; Cit-C = citação crítica; Jul = julgamento; $\mathrm{LVA}=$ leitura em voz alta; Inc = inclassificável; $\mathrm{PCR}=$ processamento cognitivo rotineiro; $\mathrm{PCE}=$ processamento cognitivo exploratório; $\mathrm{AX}=$ Aluno $\mathrm{X}$, sendo $\mathrm{X}$ de 1 a 5.

- Unidades de análise: destacamos que a divisão das exposições verbais em unidades de mensagem não foi feita considerando-se a estrutura gramatical ou a extensão da mensagem, mas sim a capacidade de transmitir com clareza uma das funções previamente definidas, sendo possível que uma exposição verbal faça referência a mais de uma função de fala ao mesmo tempo. Porém, optamos por fazer apenas uma classificação por unidade de mensagem. Sendo assim, decidimos que, na situação de dubiedade da função de fala, ela seria classificada com a função que melhor se encaixasse no conjunto e no direcionamento da atividade. Ou seja, a classificação das unidades foi feita dando-se ênfase à análise do meio e do momento em que foram proferidas.

- Trechos inclassificáveis: no decorrer do desenvolvimento do mapa, deparamo-nos com determinados trechos impossíveis de serem classificados dentre as funções de fala estabelecidas, juntamente com outros que se apresentavam de forma incompleta. Em ambas as situações, definimos os referidos trechos como inclassificáveis e representados pela sigla "Inc".

- Funções "citação crítica" versus "julgamento": ressaltamos, ainda, que algumas das funções de fala definidas na primeira dimensão podem parecer pouco compreensíveis à primeira vista, cabendo aqui uma explanação sobre cada uma delas: a função de fala do tipo "julgamento" pode ser confundida com a função do tipo "citação crítica" se não forem guardados os devidos cuidados. A primeira diz respeito ao ato de concordar ou discordar de forma direta e objetiva, sem apresentar argumentos favoráveis ou desfavoráveis frente a uma atitude ou ideia apresentada dentro da atividade. Já a função do tipo "citação crítica" pressupõe a concordância ou discordância em relação a uma ideia ou fato acontecido dentro do grupo, com a apresentação de uma explanação que baseie essa opinião. Dessa forma, o fator mais importante para a diferenciação dessas funções é a apresentação ou não de uma explanação com caráter crítico. Cabe lembrar que a citação crítica pode fazer referência ao conteúdo que está em discussão e também às ações demandadas dentro do grupo.

- Funções "julgamento" versus "avaliação": cabe ressaltar a diferença entre a função de fala do tipo "julgamento" e a função de fala do tipo "avaliação". A primeira, como dito anteriormente, faz referência ao ato de concordar ou não com uma ideia ou ação. Já a segunda diz respeito ao ato de avaliar uma ação ou ideia apresen- 
tada por um aluno ou pelo grupo, atribuindo-lhe uma qualificação positiva ou negativa. Outra função que exige esclarecimento é a função do tipo "experiencial". Ela é caracterizada nos contextos nos quais o aluno se refere a uma situação vivenciada por ele ou pelo grupo, desde que ele se inclua na ação mencionada, como por exemplo: "Nós fizemos", "A gente já entregou". Essa função também pode fazer referência a uma caracterísitica ou habilidade própria que está sendo apresentada, como exemplo: "Eu sei”, "Fui eu que fiz".

- Função "leitura em voz alta": essa função também exige esclarecimento, não pelo fato de poder ser confundida, mas sim por ser uma função que depende diretamente do conhecimento das ações que estão sendo realizadas dentro dos grupos. Entendemos que, quando um aluno faz uma leitura em voz alta, ele a faz com um objetivo que gera uma segunda função, como resposta a uma pergunta, elaboração de uma pergunta, organização do grupo ou simplesmente informação ao grupo. Dessa forma, essa função é a única que aceita uma segunda classificação.

- Função "organização de ideia" versus "resposta direta ou crítica": a função "organização de ideia" faz-se presente quando o aluno tenta organizar ideias expressas anteriormente para formar uma resposta ou para melhorar uma resposta já formulada, assim como pode aparecer com o objetivo de sumarizar ideias expressas anteriormente. Já a função do tipo "resposta" faz referência direta a uma pergunta feita anteriormente. Mais uma vez, denotamos a importância de se verificar as funções não só pelas mensagens em si mesmas, mas também pelo contexto em que se encontram.

\section{RESULTADOS E DISCUSSÃO}

As interações discursivas estabelecidas nos grupos cooperativos e colaborativos foram analisadas com base nas três dimensões mencionadas, conforme exposto a seguir.

\section{Análise da primeira dimensão: funções de fala}

A Tabela 1 ilustra a frequência, extraída dos dados obtidos a partir dos mapas analíticos, expressa em porcentagem, em que cada função de fala foi utilizada nos grupos cooperativos jigsaw e nos grupos colaborativos PLTL. Nele constam os dados obtidos para o Grupo 1 e para o Grupo 2 nas três atividades cooperativas (primeira e terceira atividades realizadas nos grupos de base, AT1 e AT3, e segunda atividade no grupo de especialistas, AT2) e para o Grupo 3 e para o Grupo 4 nas três atividades colaborativas (AT1, AT2 e AT3).

Para as funções de fala que compõem o primeiro bloco (interrogação, resposta, complemento de resposta, informação e leitura em voz alta), encontramos somatória com valores entre $37,8 \%$ e 52,2\% para os dois grupos cooperativos e encontramos somatórias com valores entre $47,7 \%$ e $52,6 \%$ para os dois grupos colaborativos. Observa-se que os grupos colaborativos, em média, apresentaram somatórias superiores às apresentadas pelos grupos cooperativos. De fato, das quatro maiores porcentagens de ocorrência no que diz respeito às funções do primeiro bloco, três foram localizadas nas atividades colaborativas $(51,4 \% ; 51,9 \%$ e $52,6 \%)$, enquanto o maior valor encontrado para os grupos cooperativos foi de 52,2\%. Apesar das diferenças encontradas, os valores, de uma forma geral, foram significativos para os quatro grupos, o que indica que os alunos se mantiveram dedicados à resolução das atividades nos grupos cooperativos e colaborativos. Dessa forma, o resultado mostra que as diferentes estruturas não afetaram o comprometimento dos alunos frente à atividade. Algumas peculiaridades, no entanto, distinguem as interações estabelecidas em cada uma das estratégias.

Conforme ilustra a Tabela 1, os grupos cooperativos e os grupos colaborativos fizeram uso similar das funções de fala dos tipos interrogação, resposta direta e leitura em voz alta. Para as funções de interrogação, encontramos valores entre $17,1 \%$ e $22,3 \%$ para os grupos cooperativos e valores entre $15,5 \%$ e $26,4 \%$ para os grupos

Tabela 1. Frequência das funções de fala em porcentagem para os grupos cooperativos e para os grupos colaborativos

\begin{tabular}{|c|c|c|c|c|c|c|c|c|c|c|c|c|c|}
\hline & & \multicolumn{6}{|c|}{ Cooperativos } & \multicolumn{6}{|c|}{ Colaborativos } \\
\hline & & \multicolumn{2}{|c|}{$\begin{array}{l}\text { Grupo } 1 \text { (G1) e } \\
\text { Grupo } 2 \text { (G2) }\end{array}$} & \multicolumn{2}{|c|}{$\begin{array}{c}\text { Grupo de } \\
\text { Especialistas }\end{array}$} & \multicolumn{2}{|c|}{$\begin{array}{l}\text { Grupo } 1 \text { (G1) e } \\
\text { Grupo } 2 \text { (G2) }\end{array}$} & \multicolumn{3}{|c|}{ Grupo 3} & \multicolumn{3}{|c|}{ Grupo 4} \\
\hline & & AT1 (G1) & AT1 (G2) & AT2 & AT2 & AT3 (G1) & AT3 (G2) & AT1 & AT2 & AT3 & AT1 & AT2 & AT3 \\
\hline \multirow{6}{*}{ Bloco 1} & Int & 21,9 & 17,1 & 22,3 & 21,6 & 21,2 & 20,6 & 23,2 & 22,2 & 26,4 & 20,1 & 15,5 & 21,9 \\
\hline & Res & 8,9 & 9,9 & 14,3 & 12,9 & 11,5 & 13 & 11,9 & 11,4 & 13,1 & 10,8 & 7,4 & 10,3 \\
\hline & C-Res & 1,0 & 9,3 & 1,7 & 3,7 & 2,6 & 2,3 & 4,4 & 4,1 & 4,7 & 9,3 & 6,1 & 4,4 \\
\hline & Inf & 2,3 & 10,8 & 5,7 & 5,9 & 9,3 & 3,7 & 4,2 & 9,5 & 5,7 & 6,5 & 12,8 & 11,7 \\
\hline & LVA & 3,7 & 5,1 & 1,1 & 5,5 & 3,0 & 4,3 & 4,2 & 5,4 & 2,0 & 2,8 & 5,9 & 3,1 \\
\hline & Soma & 37,8 & 52,2 & 45,1 & 49,6 & 47,6 & 43,9 & 47,9 & 52,6 & 51,9 & 49,5 & 47,7 & 51,4 \\
\hline \multirow{6}{*}{ Bloco 2} & Org-A & 18,0 & 9,3 & 5,7 & 12,9 & 15,2 & 17,3 & 8,3 & 7,0 & 7,2 & 11,4 & 8,7 & 13,9 \\
\hline & Exp & 3,9 & 4,8 & 5,1 & 2,7 & 2,6 & 6,3 & 4,6 & 5,1 & 7,6 & 4,0 & 6,1 & 4,2 \\
\hline & Jul & 8,6 & 11,4 & 12 & 8,2 & 7,4 & 7,6 & 8,1 & 9,8 & 7,2 & 8,0 & 9,6 & 8,1 \\
\hline & Ava & 2,6 & 1,2 & 1,7 & 4,3 & 3,0 & 3,3 & 2,1 & 2,9 & 3,2 & 2,8 & 4,1 & 1,7 \\
\hline & Afe & 2,4 & 0,6 & 0,6 & 1,4 & 0,7 & 4 & 0,2 & 0,3 & 1,5 & 0,3 & 0,4 & 0,8 \\
\hline & Soma & 35,5 & 27,3 & 25,1 & 29,5 & 28,9 & 38,5 & 23,3 & 25,1 & 26,7 & 26,5 & 28,9 & 28,7 \\
\hline \multirow{5}{*}{ Bloco 3} & Cit-C & 5,2 & 3 & 6,3 & 5,7 & 10,0 & 4 & 7,3 & 5,4 & 4,2 & 2,5 & 2,6 & 2,5 \\
\hline & Org-I & 6,0 & 6,4 & 3,5 & 6,5 & 2,3 & 1 & 8,6 & 2,9 & 5,4 & 5,6 & 2,0 & 4,2 \\
\hline & Res-C & 5,5 & 3,3 & 4,6 & 2,3 & 4,5 & 4 & 5,0 & 6,7 & 3,4 & 3,7 & 1,2 & 4,4 \\
\hline & C-Res-C & 9,9 & 7,8 & 15,4 & 6,4 & 6,7 & 8,6 & 7,9 & 7,3 & 8,4 & 12,3 & 17,6 & 8,9 \\
\hline & Soma & 26,6 & 20,5 & 29,8 & 20,9 & 23,5 & 17,6 & 28,8 & 22,3 & 21,4 & 24,1 & 23,4 & 20 \\
\hline
\end{tabular}

Int = interrogação; Res= resposta; C-Res= complemento de resposta; Inf= informação; LVA= leitura em voz alta; Org-A= organização de ação; Exp= experencial; Jul= julgamento; Ava= avaliação; Afe= afetiva; Cit-C= citação crítica; Org-I organização de ideia; Res-C= resposta crítica e C-Res-C= complemento de resposta crítica. 
colaborativos. Para as funções de resposta direta encontramos valores entre $8,9 \%$ e $14,3 \%$ para os grupos cooperativos e valores entre $7,4 \%$ e 13,1\% para os grupos colaborativos. Já para a função de fala leitura em voz alta, encontramos valores entre $3,0 \%$ e $5,5 \%$ para cinco das seis atividades dos grupos cooperativos, sendo que apenas a atividade do grupo de especialistas apresentou um valor relativamente menor do que as demais $(1,1 \%)$, e valores entre $2,0 \%$ e $5,9 \%$ para os grupos colaborativos.

Os valores citados revelam que ambas as estratégias geraram atividades com caráter objetivo, nas quais os alunos apresentaram uma postura de busca à resolução da atividade e usaram as referidas funções para conduzir suas ações.

O Quadro 5 apresenta trechos do mapa analítico da primeira atividade cooperativa do Grupo $1 \mathrm{e}$ da primeira atividade colaborativa do Grupo 3. Nele são apresentados os fragmentos que evidenciam a forma como as funções de fala interrogação resposta e leitura em voz alta são utilizadas nos dois formatos (jigsaw e PLTL).

Os fragmentos 1 e 2 ilustram como os grupos cooperativos e colaborativos usam as referidas funções de forma semelhante para conduzir suas atividades. No fragmento 1, o aluno A5 faz uso da função de fala de interrogação, que em seguida é respondida de forma direta pelo aluno A1. Na parte final do trecho, o aluno A1 faz uso da função de fala interrogação e ele mesmo finaliza o trecho fazendo uma leitura em voz alta, que tem como objetivo responder a sua indagação. Ressaltamos a forma como o Aluno A1 busca, com sua pergunta, verificar se o aluno A5 entendeu o que foi exposto e sua preocupação em ajudá-lo.

No fragmento 2, de forma similar, os alunos A1, A2 e A3 conduzem a atividade usando as funções referidas, começando com o aluno A1, que faz uso da função de fala leitura em voz alta, que tem como objetivo complementar de forma direta uma pergunta anterior. Essa inferência faz com que o aluno A3 faça uso do mesmo tipo de função leitura em voz alta, com objetivo de interrogar seus pares. Em seguida, o aluno A2 responde de forma direta, o que leva a outras inferências. Nos dois fragmentos os alunos direcionam a resolução da atividade com o uso das três funções em questão, fato que justifica os valores semelhantes encontrados para as duas estratégias.

Com relação às funções de fala informação e complemento de resposta direta, percebemos que em ambas as estratégias os alunos usaram as referidas funções para auxiliar na realização das atividades.
Entretanto, para essas funções encontramos valores diferentes em relação às duas estratégias. Para a função de fala do tipo complemento de resposta direta, com exceção do valor $9,3 \%$, que se repetiu na primeira atividade cooperativa do Grupo 2 e na primeira atividade do Grupo 3, relativamente maior que as demais para as duas estratégias, encontramos valores entre $1,0 \%$ e $3,7 \%$ nos grupos cooperativos, enquanto nos grupos colaborativos encontramos valores entre $4,1 \%$ e $6,1 \%$. Os valores superiores encontrados indicam que as respostas diretas e seus complementos se mostram suficientes para direcionar os grupos colaborativos no decorrer das atividades, como ilustram os Fragmentos 3 e 4 do Quadro 6. Nele os alunos dos Grupos 3 e 4 fazem uso das diferentes funções do primeiro bloco para direcionar sua atividade e fecham suas respostas com um ou mais complementos de respostas diretas, que no caso se mostram suficientes para conduzir a atividade colaborativa, fato que não acontece nos grupos cooperativos de forma tão pronunciada. Ou seja, os fragmentos que evidenciam a forma como as funções de fala do tipo interrogação, resposta e complemento de resposta se interligam para permitir que os alunos elaborem suas respostas de forma colaborativa. O líderpar, que fomenta o engajamento entre os membros do grupo, pode ser considerado, pelo menos parcialmente, como responsável pelo desencadeamento desse processo mais efetivo de respostas diretas e seus complementos.

Para a função de fala de informação encontramos para ambas as estratégias valores bem variados. Para os grupos cooperativos encontramos valores entre $2,3 \%$ e $10,8 \%$ e para os grupos colaborativos encontramos valores entre $4,2 \%$ e $12,8 \%$. Apesar de a variação ter aparecido nas duas estratégias, chama a atenção o fato de os grupos cooperativos não apresentarem nenhuma tendência (enquanto os valores aumentam entre a primeira $(2,3 \%)$ e a terceira atividade $(9,3 \%)$ no Grupo 1 , no Grupo 2 há uma diminuição de $10,8 \%$ na primeira atividade para $3,7 \%$ na terceira atividade). Já nos grupos colaborativos percebe-se que ocorre um aumento da primeira para a terceira de $4,2 \%$ para $5,7 \%$ no Grupo 3 , e de $6,5 \%$ para $12,8 \%$ no Grupo 4. Novamente, a presença do líder-par pode justificar esse aumento, pela mesma razão citada na função do tipo complemento de resposta direta.

Conforme ilustra a Tabela 1, para as funções de fala que compõem o segundo bloco (organização de ação, experiencial, julgamento, avaliação e afetiva), nos grupos cooperativos a somatória apresentou

Quadro 5. Trechos do mapa analítico das interações ocorridas na primeira atividade cooperativa do Grupo 1 (Fragmento 1) e na primeira atividade colaborativa do Grupo 3 (Fragmento 2)

\begin{tabular}{|c|c|c|c|c|}
\hline $\mathbf{N}^{\circ}$ & Função de fala & Fragmento 1 & & Agente \\
\hline 187 & Int & Não é? & PCR & A5 \\
\hline 188 & Res & É que ele colocou aqui para ver como vamos escrever. & PCR & A1 \\
\hline 189 & Org-I & $\begin{array}{c}\text { As reações não param, apesar de a gente, olhando, parecer que elas pararam, que a reação } \\
\text { parou. }\end{array}$ & PCE & A1 \\
\hline 190 & Int & Hum? & PCR & A5 \\
\hline 191 & Int & Entendeu? & PCR & A1 \\
\hline 192 & LVA/Res & Ele colocou assim: apesar de visualmente parecer que a reação para. & PCR & A1 \\
\hline $\mathbf{N}^{\circ}$ & Função de fala & Fragmento 2 & & Agente \\
\hline 254 & LVA/C-Res & Bom, o equilíbrio químico da substância água pode ajudar. & PCR & A1 \\
\hline 255 & Org-A & Abre aí porque não dá para ler tudo. & PCR & A1 \\
\hline 256 & LVA/Int & O equilíbrio químico da substância água pode definir ácidos base e pH? Se sim, indique como. & PCR & A3 \\
\hline 257 & Res & Não. & PCR & A2 \\
\hline 258 & Int & A cinco você manja bastante, não é? & PCR & A2 \\
\hline 259 & Int & O quê? & PCR & $\mathrm{A} 3$ \\
\hline 260 & Res & A cinco. & PCR & $\mathrm{A} 2$ \\
\hline
\end{tabular}


Quadro 6. Trechos do mapa analítico das interações ocorridas na primeira atividade dos Grupos 3 (Fragmento 3) e 4 (Fragmento 4)

\begin{tabular}{|c|c|c|c|c|}
\hline $\mathbf{N}^{\circ}$ & Função de fala & Fragmento 3 & & $\mathbf{N}^{\circ}$ \\
\hline 391 & Int & Mas e aí, como é que a gente vai escrever? & PCR & A1 \\
\hline 392 & Org-I & A gente fala que a água serve como parâmetro. & PCR & A3 \\
\hline 393 & Res & Para alguns resultados. & PCR & $\mathrm{A} 2$ \\
\hline 394 & Int & Como? & PCR & A1 \\
\hline 396 & C-Res & É só um referencial. & PCR & A2 \\
\hline $\mathbf{N}^{\circ}$ & Função de fala & Fragmento 4 & & Agente \\
\hline 22 & Int & Será que é essa que a entropia está sempre aumentando? & PCR & $\mathrm{A} 3$ \\
\hline 23 & Res & Acho que é. & PCR & A4 \\
\hline 24 & C-Res & É o que ele colocou na transparência. & PCR & A4 \\
\hline 25 & C-Res & É o que estava no slide, na transparência. & PCR & $\mathrm{A} 2$ \\
\hline
\end{tabular}

valores entre $25,1 \%$ e $38,5 \%$, enquanto para os grupos colaborativos a somatória apresentou valores entre $23,3 \%$ e $28,9 \%$. Os valores encontrados para os dois grupos cooperativos apresentaram uma variação considerável no decorrer das atividades, não sendo identificada nenhuma tendência. Diferentemente, para os grupos colaborativos percebemos pouca variação, com valores entre $23,3 \%$ e $26,7 \%$ para o Grupo 3 e valores entre 26,5\% e 28,9\% para o Grupo 4. Somado a isso, apontamos o aumento gradativo no uso dessas funções da primeira para terceira atividade.

Os valores encontrados para a função de fala do tipo organização de ação foram relativamente superiores nos grupos cooperativos frente aos encontrados para os colaborativos. De fato, as três maiores porcentagens de ocorrência no que diz respeito à função organização de ação foram localizados nos grupos cooperativos $(15,2 \% ; 17,3 \%$ e $18,0 \%$ ), enquanto o maior valor encontrado para os grupos colaborativos foi de $13,9 \%$. Relacionamos as diferenças encontradas com a diferença na estrutura de cada estratégia, tendo em vista que o uso de cada função permite que os alunos organizem e direcionem a atividade, de modo que o uso significativo dessa função se revela mais pronunciado em atividades mais estruturadas.

Para a função de fala do tipo experiencial, encontramos valores entre $2,6 \%$ e $6,3 \%$ para os grupos cooperativos e valores entre $4,0 \%$ e $7,6 \%$ para os grupos colaborativos. A pequena diferença encontrada para a referida função sugere que os alunos dos grupos colaborativos encontraram dentro das suas atividades mais oportunidades de compartilhar suas experiências com seus pares do que os alunos do grupo cooperativo. Relacionamos essa diferença, mesmo que pequena, à estrutura dos grupos colaborativos, que é menos estruturada, o que oferece ao aluno maior liberdade dentro do grupo, e também à formação dos grupos, lembrando que apenas os grupos cooperativos foram formados de forma heterogênea e, como consequência, os alunos não se agruparam por empatia, como aconteceu nos grupos colaborativos. Cabe aqui salientar que ao afirmarmos que a estrutura dos grupos colaborativos é menos estruturada que a dos grupos cooperativos não implica que os do primeiro tipo sejam menos significativos, ou de menor valor, que os do segundo. A estrutura do grupo colaborativo é orgânica, seguindo uma estruturação que não foi imposta por terceiros, como no grupo cooperativo, tampouco foi delimitado aos seus membros os subtópicos específicos sobre os quais deveriam se empenhar para a execução das tarefas. Assim, os grupos colaborativos seguem uma estruturação que se debruça sobre aspectos afetivos.

Para as funções de fala do tipo, julgamento, avaliação e afetiva encontramos valores semelhantes para os grupos cooperativos e colaborativos. Para a função de fala afetiva foram encontrados resultados poucos expressivos para as duas estratégias, na sua maioria inferiores a $1,5 \%$, com apenas dois valores destoantes dos demais, sendo eles $2,4 \%$ para a primeira atividade cooperativa do Grupo 1 e $4,0 \%$ para terceira atividade cooperativa do Grupo 2. Para a função de fala do tipo julgamento, encontramos valores entre $7,4 \%$ e $12 \%$ para os grupos cooperativos e valores entre 7,2\% e 9,8\% para os grupos colaborativos. Para a função de fala do tipo avaliação, encontramos valores de $1,2 \%$ e $4,3 \%$ para os grupos cooperativos e valores entre $1,7 \%$ e $4,1 \%$ para os grupos colaborativos. O uso similar encontrado para as três funções nas duas estratégias indica que, mesmo frente a diferenças estruturais, os alunos que participaram de ambas sentiram a necessidade e tiveram a liberdade de julgar e avaliar seus pares, tanto nos grupos cooperativos quanto nos grupos colaborativos.

Conforme ilustra a Tabela 1, para as funções de fala que compõem o terceiro bloco (organização de ideia, citação crítica, resposta crítica e complemento de resposta crítica) encontramos valores similares para as duas estratégias. A somatória dessas funções para os grupos cooperativos apresentou valores entre $17,6 \%$ e $29,8 \%$. Já para os grupos colaborativos, encontramos somatória entre $20 \%$ e $28,8 \%$. Os valores sugerem que os alunos das duas estratégias participaram de atividades que exigiram respostas críticas e reflexivas.

Os valores encontrados para a função citação crítica para os grupos cooperativos foram relativamente maiores do que os encontrados para os grupos colaborativos. De fato, dentre as quatro maiores porcentagens de ocorrência no que diz respeito à função de citação crítica, três foram localizadas nos grupos cooperativos $(5,7 \%$, $6,3 \%$ e $10 \%$ ), enquanto o maior valor encontrado para os grupos colaborativos foi de 7,3\%. Os valores também denotaram tendências diferentes nas duas estratégias. Para os dois grupos cooperativos, observou-se um aumento no uso da referida função da primeira para a terceira atividade, enquanto para as atividades colaborativas do Grupo 3 encontramos uma redução e para o Grupo 4 os valores não mudaram. Os valores mais elevados na terceira atividade dos grupos cooperativos, provavelmente, relacionam-se à estrutura da atividade, que exige a formação dos grupos de especialistas, fazendo com que os alunos voltem para os seus grupos de base com um conhecimento aprofundado de um determinado assunto, o que gera postura mais crítica frente ao tema trabalhado, como se observa a seguir.

O Quadro 7 apresenta trechos do mapa analítico da terceira atividade cooperativa dos Grupos 1 e 2. Nele são apresentados os fragmentos 5 e 6 , que evidenciam o uso da função citação crítica.

No fragmento 5, após o aluno A3 fazer um complemento de resposta crítica, o aluno A1 faz uma citação crítica e, em seguida, faz um novo complemento crítico para a resposta. Observa-se que a citação crítica apresenta um embasamento teórico substancial sobre a temática equilíbrio químico, que era um dos temas estudados pelo grupo de especialistas. Denotamos, ainda, que os fragmentos foram extraídos de interações discursivas ocorridas no início da terceira atividade (retorno aos grupos de base), mostrando que o aluno 
Quadro 7. Trechos do mapa analítico das interações ocorridas na terceira atividade cooperativa do Grupo 1 (Fragmento 5) e na terceira atividade cooperativa do Grupo 2 (Fragmento 6)

\begin{tabular}{|c|c|c|c|}
\hline $\mathbf{N}^{\circ}$ & $\begin{array}{l}\text { Função } \\
\text { de fala }\end{array}$ & Fragmento 5 & Agente \\
\hline 31 & C-Res-C & $\begin{array}{l}\text { Ela pode ser reversível em qualquer } \\
\text { momento. }\end{array}$ & A3 \\
\hline 32 & Cit-C & $\begin{array}{l}\text { Não. Reversibilidade nesse caso não } \\
\text { é em relação ao processo reversível. } \\
\text { Reversibilidade, nesse caso, é só em } \\
\text { relação à reação direta ou inversa. }\end{array}$ & A1 \\
\hline 33 & C-Res-C & $\begin{array}{l}\text { Por exemplo, o equilíbrio tem a com- } \\
\text { posição do sistema e a composição do } \\
\text { sistema tem uma determinada variação } \\
\text { de energia livre. E ela vai tendendo até } \\
\text { a variação de energia ser igual a zero. }\end{array}$ & A1 \\
\hline $\mathbf{N}^{\circ}$ & $\begin{array}{l}\text { Função } \\
\text { de fala }\end{array}$ & Fragmento 6 & Agente \\
\hline 102 & C-Res-C & O pH continua constante. & A4 \\
\hline 103 & Cit-C & $\begin{array}{l}\text { Sim, mas se o pH do sangue mudar, } \\
\text { o ferro, se não me engano, que está } \\
\text { no sangue. }\end{array}$ & A1 \\
\hline 104 & C-Res-C & $\begin{array}{l}\text { Pode desequilibrar várias coisas no } \\
\text { corpo. }\end{array}$ & A4 \\
\hline 105 & Org-A & $\begin{array}{l}\text { Mas calma, não é isso que quero } \\
\text { explicar. }\end{array}$ & $\mathrm{A} 1$ \\
\hline
\end{tabular}

trouxe consigo conhecimentos específicos para executá-la. De forma semelhante, no fragmento 6 o aluno A1 faz uso da função de citação crítica, mas neste caso o embasamento teórico é relativo ao tema ácido e base, outro tema específico estudado nos grupos de especialistas, o que corrobora os resultados e apontamentos realizados.

Para a função de fala do tipo organização de ideia encontramos variações nos valores das duas estratégias, com valores entre 1,0\% e $6,5 \%$ para os grupos cooperativos e valores entre $2,0 \%$ e $8,6 \%$ para os grupos colaborativos. Apesar da variação em ambas as estratégias, destacamos que foram encontradas tendências nos valores apresentados para ambos os tipos de grupos. Para os grupos colaborativos, tanto o Grupo 3 quanto o Grupo 4, ocorreu uma queda na frequência da função da atividade 1 para a atividade 2 e, posteriormente, uma elevação desta última para a atividade 3. É possível especular que isso ocorra uma vez que, após a discussão do tema e o direcionamento dos alunos para uma nova atividade mais complexa, as organizações das ideias são novamente dialogadas e discutidas de forma mais elaborada entre os pares.

No que diz respeito aos grupos cooperativos, observa-se que o Grupo 1 apresenta uma tendência de dirimir a organização de ideias de

A.

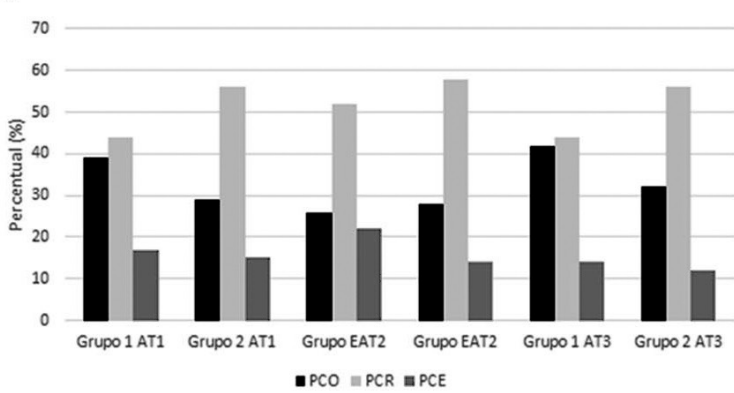

forma gradual da atividade 1 para a atividade 3 . O que pode sinalizar um posicionamento efetivo da participação dos alunos no grupo de especialistas, sinalizando um papel de componente organizador para respostas críticas, como apontado no Quadro 7.

Em contraponto, o Grupo 2 apresenta um comportamento similar ao dos grupos colaborativos entre as atividades $1 \mathrm{e} 2$, com um pequeno aumento da organização de ideias. Contudo, esse comportamento diminui consideravelmente da atividade 2 para a atividade 3 . Isso pode sinalizar uma maior evidência das respostas críticas, como fundamentando a condução das discussões entre os componentes dos grupos, após a volta dos alunos do grupo de especialistas.

Com relação às funções de fala resposta crítica e complemento de resposta crítica, percebemos que os alunos fizeram uso similar dessas funções nas duas estratégias, com valores entre $2,3 \%$ e $5,5 \%$ para as atividades dos grupos cooperativos no que se refere à função de resposta crítica, e com valores entre $1,2 \%$ e 6,7\% para as atividades dos grupos colaborativos para a mesma função. Já para a função de fala complemento de resposta crítica foram encontrados valores entre $6,4 \%$ e $15,4 \%$ para os grupos cooperativos e valores entre $7,3 \%$ e $17,6 \%$ para os grupos colaborativos. Os resultados sugerem que o uso das duas funções não foi afetado substancialmente pela estrutura específica das estratégias.

\section{Análise da segunda dimensão: processamento cognitivo}

Na Figura 1 apresentamos a frequência expressa em porcentagem em que cada processamento cognitivo foi utilizado nos grupos cooperativos e nos grupos colaborativos nas três atividades. A letra "E" representa as atividades desenvolvidas pelo grupo de especialistas.

A análise da Figura 1 indica a seguinte tendência para a ocorrência dos processamentos cognitivos nos grupos: o uso do processamento cognitivo rotineiro foi superior em todos os grupos, nas três atividades nas duas estratégias; o processamento cognitivo off-task foi o segundo mais recorrente em nove das 12 atividades analisadas; o processamento cognitivo exploratório foi o menos recorrente em nove das 12 atividades analisadas. No que diz respeito ao processamento cognitivo rotineiro, os valores encontrados para os grupos colaborativos foram relativamente maiores do que os encontrados para os grupos cooperativos. De fato, as três maiores porcentagens de ocorrência no que diz respeito ao processamento cognitivo rotineiro foram aí encontrados $(62 \%, 69 \%$ e $88 \%)$, enquanto o maior valor encontrado para os grupos cooperativos foi de $58 \%$. Os valores elevados encontrados para os grupos colaborativos denotam que o trabalho aí realizado apresentou um caráter consideravelmente rotineiro, o que reforça os valores encontrados para os grupos colaborativos no que diz respeito ao uso superior das funções de fala do primeiro bloco.

B.

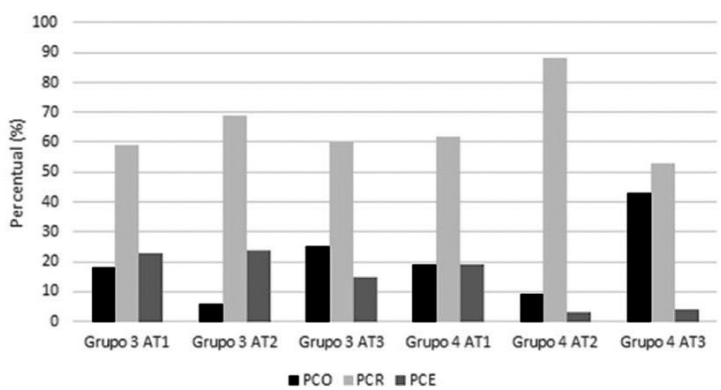

Figura 1. Porcentagem de uso dos processamentos cognitivos durante a resolução das três atividades cooperativas nos Grupo 1 e 2 (a) e das três atividades colaborativas nos Grupos 3 e 4 (b), AT1 = primeira atividade, AT2 = segunda atividade, AT3 = terceira atividade e EAT = atividade desenvolvida pelo grupo de especialistas 
Os valores encontrados para o processamento cognitivo exploratório revelaram comportamentos bem definidos para as duas estratégias, tendo os grupos cooperativos apresentado uso significativo, com pequena redução da primeira para terceira atividade. De forma semelhante, nos grupos colaborativos encontramos uma redução da primeira para a terceira atividade. Ainda com relação ao processamento cognitivo exploratório, ressaltamos a ampla faixa de valores encontrados para os grupos colaborativos. De fato, ocorre variação que vai de $3 \%$ a $24 \%$ para a mesma estratégia. O que reafirma o caráter irregular das atividades colaborativas na perspectiva dos processamentos cognitivos. Assim, embora tenhamos observado uso significativo das funções de caráter crítico (terceiro bloco) para ambos os grupos colaborativos, este uso não implica, necessariamente, no desencadeamento de processamento cognitivo exploratório.

O Quadro 8 apresenta trecho do mapa analítico da terceira atividade colaborativa do Grupo 4, e da terceira atividade cooperativa do Grupo 2. Nele são apresentados fragmentos que evidenciam a relação entre as funções de fala, principalmente do terceiro bloco, e o processamento cognitivo.

No fragmento 7 o trecho inicia com o aluno A3 complementando uma resposta de forma crítica e com caráter exploratório, em seguida o aluno A2 sugere uma nova resposta crítica, mas não dá continuidade ao caráter exploratório. Novamente, o aluno A3 faz uma interrogação com caráter exploratório, e por fim, o fragmento é finalizado com o aluno A4 respondendo de forma crítica, mas não dando continuidade ao caráter exploratório. Chama atenção o fato de que uma resposta com embasamento teórico garante o caráter crítico, mas não o caráter exploratório da atividade. Diferentemente, o fragmento 8 inicia-se com o aluno A1 realizando uma interrogação que, dentro do contexto, apresenta um caráter exploratório já que instiga o aluno A4 a fazer um complemento crítico direcionado para a interrogação realizada. Em seguida, o aluno A1 complementa também de forma crítica e finaliza com uma citação crítica que não tem como objetivo fechar a discussão e sim fornecer mais elementos para análise. Fato que justifica os valores encontrados para o processamento cognitivo exploratório para as duas estratégias.

Por fim, ao analisarmos comparativamente a frequência do processamento cognitivo off-task, verificamos que os grupos apresentaram tendências destoantes quando se verificam as atividades de forma sequencial, da primeira para a terceira. Assim, para os grupos colaborativos valores vão de $18 \%$ na primeira atividade para $26 \%$ para o Grupo 3, e de $19 \%$ na primeira atividade para $43 \%$ na terceira para o Grupo 4. $\mathrm{O}$ uso elevado desse processamento na terceira atividade de forma similar para os dois grupos justifica-se pelo seu caráter finalizador, o que leva os alunos a apresentarem um comportamento mais descontraído na última atividade do que nas demais. Já para os grupos cooperativos os valores apresentam uma pequena variação nos dois grupos, de $38 \%$ para $42 \%$ no Grupo 1 , e de $29 \%$ para $32 \%$ no Grupo 2. Relacionamos a consistência nos valores encontrados para os grupos cooperativos com a estrutura das atividades que permite, mesmo durante a sua finalização, o estabelecimento de um ambiente descontraído, mas sem que se observem distrações que comprometam a execução da atividade.

\section{Análise da terceira dimensão: processamento social}

A Figura 2 ilustra os tipos de interações sociais considerados, assim como a porcentagem com que cada um foi utilizado nos grupos cooperativos e nos grupos colaborativos nas três atividades.

Em praticamente todas as atividades cooperativas e colaborativas o processamento social colaborativo foi predominante. $\mathrm{O}$ valor de $31 \%$, encontrado para a segunda atividade do Grupo 4, é o único que

Quadro 8. Trechos do mapa analítico das interações ocorridas na terceira atividade colaborativa do Grupo 4 (Fragmento 7) e da terceira atividade cooperativa do Grupo 2 (Fragmento 8)

\begin{tabular}{|c|c|c|c|c|}
\hline $\mathbf{N}^{\circ}$ & Função de fala & Fragmento 7 & & Agente \\
\hline 289 & C-Res-C & Então olha, como que vai formar isso aqui $\left(\mathrm{H}_{3} \mathrm{O}+2 \mathrm{NO}_{2}+\mathrm{K}^{+}\right)$ & PCE & A3 \\
\hline 290 & Res-C & Eu tenho a impressão que essa primeira é uma solução tampão. & PCR & $\mathrm{A} 2$ \\
\hline 291 & Int & $\mathrm{NO}_{2}$, olha gente, é isso aqui o equilíbrio, vocês concordam comigo? & PCE & A3 \\
\hline 292 & Res-C & Vai dar $\mathrm{NO}_{2}$. & PCR & A4 \\
\hline $\mathbf{N}^{\circ}$ & Função de fala & Fragmento 8 & & Agente \\
\hline 99 & Int & É isso que está pedindo? & PCE & A1 \\
\hline 100 & C-Res-C & $\begin{array}{c}\text { Porque qualquer reação que acontece no nosso corpo, não vai desequilibrá-lo, entende, equilíbrio } \\
\text { químico. }\end{array}$ & PCE & A4 \\
\hline 102 & C-Res-C & $\mathrm{O}$ pH continua constante. & PCE & A1 \\
\hline 103 & Cit-C & Sim, mas se o pH do sangue mudar, o ferro, se não me engano, que está no sangue. & PCE & A1 \\
\hline
\end{tabular}

A.

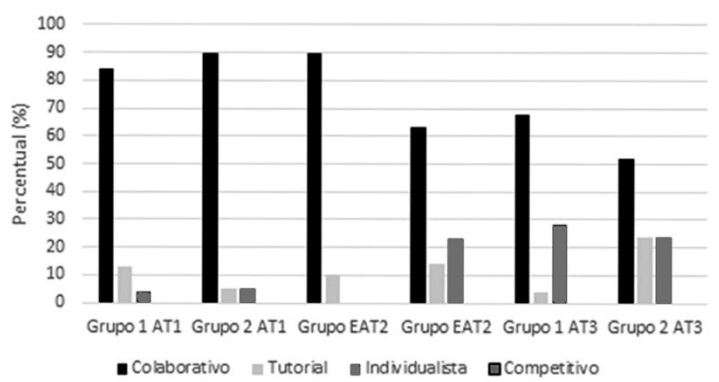

B.

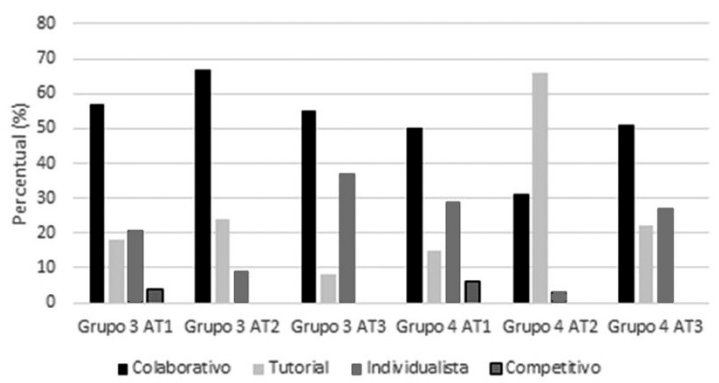

Figura 2. Porcentagem de uso dos processamentos sociais durante a resolução das três atividades dos Grupos 1 e 2 cooperativos (a) e das três atividades dos Grupos 3 e 4 colaborativos (b), AT1 = primeira atividade, AT2 = segunda atividade, AT3 = terceira atividade e EAT = atividade desenolvida pelo grupo de especialistas 
não se alinha com os demais, com predomínio do processamento tipo tutorial. Os valores revelam que, de uma forma geral, as duas estratégias tiveram a colaboração como característica social principal.

De forma semelhante ao verificado na análise da segunda dimensão para os grupos colaborativos, dentro das três atividades o processamento social colaborativo apresentou valores variáveis, não permitindo a definição de uma tendência. Já para os grupos cooperativos percebe-se uma redução nos valores encontrados na passagem da primeira para a terceira atividade nos dois grupos, com valores indo de $84 \%$ para $68 \%$ no Grupo 1 , e valores indo de $90 \%$ a $52 \%$ no Grupo 2. Tanto os resultados encontrados para os grupos cooperativos quanto para os grupos colaborativos podem ser relacionados com a estrutura especifica de cada estratégia. Nos grupos colaborativos, a variação reforça a ideia sobre a influência da falta de estrutura dos grupos que traz para a atividade uma dependência muito grande das características dos membros dos grupos. Soma-se a isso a presença do líder-par que leva os alunos a migrarem de um comportamento colaborativo para um tutorial.

Para os grupos cooperativos a influência da estrutura se relaciona com a passagem pelo grupo de especialistas que traz para a terceira atividade uma nova necessidade, já que os alunos especialistas precisam dividir o conhecimento adquirido, diminuindo assim o processamento colaborativo e aumentando o processamento tutorial. Cabe lembrar que, diferentemente da atividade colaborativa, o processamento social tutorial na atividade cooperativa parte também dos alunos.

O segundo processamento social em destaque foi o do tipo tutorial apresentando resultados significativos para os quatro grupos nas duas estratégias, com valores entre $8 \%$ e $66 \%$ para os grupos colaborativos, e valores entre $4 \%$ e $24 \%$ para os grupos cooperativos. Assim como para o processamento social colaborativo, encontramos uma grande variação para o processamento tutorial nas duas estratégias, o que reforça os resultados encontrados anteriormente para o processamento colaborativo e aponta para uma relação entre o comportamento do grupo e a estrutura das atividades. Cabe lembrar que esses resultados coadunam com os resultados encontrados nas demais dimensões.

Para o processamento social do tipo individualista destacamos o fato dele ter sido encontrado nas três atividades realizadas pelos dois grupos colaborativos com valores entre 3\% e 37\%. Já para os grupos cooperativos esse tipo de processamento social foi verificado em cinco das seis atividades, com valores entre $4 \%$ e $28 \%$. Por fim, ressaltamos os valores encontrados para o processamento social do tipo competitivo, encontrado na primeira atividade dos dois grupos colaborativos. Já para os grupos cooperativos, o referido processamento social não foi encontrado em nenhuma atividade. Relacionamos esses valores com a formação do grupo apresentada pelas diferentes estratégias, lembrando que os grupos cooperativos são montados de forma heterogênea, com alunos de diferentes características, com o objetivo de equilibrar as ações dentro da atividade. Por outro lado, os grupos colaborativos são livres e formados muitas vezes por empatia, o que leva os alunos a compartilharem momentos de máxima interação e momentos de mínima interação, quando os alunos interagem de forma não colaborativa, como revelam os valores referentes ao processamento social competitivo.

\section{CONSIDERAÇÕES FINAIS}

A discussão dos dados apresentados até o momento fornece subsídios para que possamos fazer considerações sobre a questão de pesquisa: qual é a influência da estrutura dos grupos na forma como as interações discursivas entre os participantes são estabelecidas?

Os resultados indicam que algumas das interações discursivas nos grupos estão atreladas às suas características estruturais. De fato, a existência dos grupos de especialistas na estratégia cooperativa jigsaw, embora não influencie as funções de fala do primeiro bloco, repercute principalmente em algumas das funções de fala do segundo bloco (organização de ação e avaliação) e do terceiro bloco (citação crítica e organização de ideia).

No que se refere à segunda e à terceira dimensão de análise, percebemos que a aplicação da estratégia colaborativa PLTL, pouco estruturada e com a formação não heterogênea de grupos, repercutiu nos valores não regulares encontrados para os tipos de processamentos cognitivos e de processamentos sociais. Assim, foi observado que os resultados dependem, de forma significativa, das características dos membros dos grupos. A presença do líder-par, que leva os alunos a migrarem de um comportamento colaborativo para um tutorial, também foi determinante para a obtenção dos referidos valores.

De forma geral, é ainda possível afirmar, com base no uso recorrente das funções de fala que compõem o primeiro bloco (interrogação, resposta, complemento de resposta, informação e leitura em voz alta), que os alunos se mantiveram dedicados à resolução das atividades tanto nas turmas nas quais foi aplicada a estratégia jigsaw, quanto nas que foi aplicada a estratégia PLTL. Da mesma forma, o uso, mesmo que restrito, da função de fala do tipo afetiva indica que os alunos encontraram um ambiente seguro no contexto das atividades realizadas.

Os resultados obtidos corroboram ainda algumas das potencialidades das atividades cooperativas e colaborativas em ambientes de ensino-aprendizagem de química, como a promoção da aprendizagem de conceitos científicos, o desenvolvimento de habilidades interpessoais e a instauração de um ambiente universitário acolhedor. Ademais, também evidenciam fragilidades da metodologia empregada, como a impossibilidade de verificação sobre as interações estabelecidas em um plano que não é o verbal, o que sugere a necessidade de aprimoramento do Modelo Analítico adotado neste trabalho.

Embora o percurso aqui descrito tenha ocorrido com embasamento teórico, temos ciência das limitações a ele inerentes e acreditamos que as considerações aqui tecidas não devem ser entendidas de forma estanque. Em contraponto, o conhecimento alcançado pode subsidiar interpretações sobre a forma como diferentes elementos interferem na execução das estratégias investigadas e levar o leitor a ponderar a respeito, promovendo atividades didáticas exitosas. Além disso, esperamos também contribuir para o desencadeamento de ações em ambientes universitários pautadas em atividades em grupos cooperativos e colaborativos, ainda tão escassas no nosso país.

\section{MATERIAL SUPLEMENTAR}

O material suplementar estará disponível em http://quimicanova. sbq.org.br com acesso livre e inclui os questionários aplicados durante as atividades e esquema ilustrativo das mesmas.

\section{AGRADECIMENTOS}

Ao Conselho Nacional de Desenvolvimento Científico e Tecnológico (CNPq), Processo 304974/2020-0.

\section{REFERÊNCIAS}

1. Souza, J. I. R.; Leite, Q. S. S.; Leite, B. S.; Revista Electrónica de Enseñanza de las Ciencias 2015, 5, 135.

2. Fernandez, C.; Baldinato, J. O.; Tiedemann, P. W.; Bertotti, M.; Quim. Nova 2008, 31, 1582.

3. Bertotti, M.; Quim. Nova 2011, 34, 1836. 
4. Zucco, C.; Pessine, F. B. T.; Andrade, J. B.; Quim. Nova 1999, 22, 454.

5. Massi, L.; Cerrutti, B. M.; Queiroz, S. L.; Quim. Nova 2013, 36, 897.

6. Carpenter, S. R.; McMillan, T.; J. Chem. Educ. 2003, 80, 330.

7. Gemmel, P. M.; Goetz, M. K.; James, N. M.; Jesse, K. A.; Ratliff, B. J.; J. Chem. Educ. 2020, 97, 2899.

8. Teodoro, D. L.; Pagotto, J. F.; Motheo, A. J.; Queiroz, S. L.; Quim. Nova 2011, 34, 714

9. Johnson, D. W.; Johnson, R. T.; Holubec, E. J.; Los nuevos círculos del aprendizaje: la cooperación en el aula y la escuela, Aique: Virginia, 1999.
10. Dillenbourg, P.; Collaborative-learning: cognitive and computational approaches, Elsevier: Oxford, 1999.

11. Kumpulainen, K.; Mutanen, M.; Learning and Instruction 1999, 9, 449.

12. França, A. C. G.; Marcondes, M. E. R.; Carmo, M. P.; Quim. Nova Esc. 2009, 31, 275.

13. Atkins, P. W.; Jones, L.; Princípios de química: questionando a vida moderna e o meio ambiente, Bookman: Porto Alegre, 2018.

14. Mahan, B. M.; Myers, R. J.; Química: um curso universitário, Edgar Blücher, 1995.

15. Teodoro, D. L.; Cabral, P. F. O.; Queiroz, S. L.; Alexandria 2015, 8, 21. 